\title{
Nurturing the 21st Century Skills among Undergraduate Students through the Application and Development of Weblog
}

\author{
Md Yusoff Daud ${ }^{1} \&$ Fariza Khalid ${ }^{1}$ \\ ${ }^{1}$ Faculty of Education Universiti Kebangsaan Malaysia, Malaysia \\ Correspondence: Md Yusoff Daud, Faculty of Education, Universiti Kebangsaan Malaysia, 43600 UKM Bangi, \\ Selangor, Malaysia. Tel: 601-9652-2254. E-mail: mdyusoffdaud@gmail.com
}

Received: July 22, 2014 Accepted: November 5, 2014 Online Published: December 21, 2014

doi:10.5539/ies.v7n13p123 URL: http://dx.doi.org/10.5539/ies.v7n13p123

\begin{abstract}
The integration of information and communication technology (ICT) into education is one of the main approaches to fostering twenty-first century skills in teaching and learning processes. It is therefore vital to emphasize the integration of ICT into the university-level training of pre-service teachers, in order for them to effectively facilitate students' learning. ICT literacy is one of the important skills that should be possessed by twenty-first century teachers in order for them to meet the challenges of this era of information and technology. In relation to this, it is also important that pre-service teachers gain sufficient knowledge and are able to apply it innovatively and creatively in their teaching activities. This study aims to identify pre-service teachers' views on the usage of weblogs, their benefits and their preferred ways of using weblogs. The research participants were 68 pre-service teachers who were taking the GGGE2153 (Educational Technology) course. One focus of this course is that students are required to develop creative blogs for teaching and learning based on their areas of specialization. The elements of creativity, suitability for collaboration, user-friendliness and informativeness are among the criteria that should be of concern to students. The findings from the administered questionnaire show a positive impact of creating weblogs in relation to the development of twenty-first century skills.
\end{abstract}

Keywords: teaching and learning, twenty-first century skills, weblog

\section{Introduction}

The term 'weblog', of 'blog', refers to a personalized webpage, kept by the author in reverse chronological diary form. It is kept first and foremost on the web, either on a static web page, or via a database-backed website, enabled through 'blogging' software (Rosenbloom, 2004; Walker, 2003). The various features of weblogs, including the archival of past posts by date posted, hyperlinking to other webloggers, instant publishing of web content with little technical skill required, and ways for others to comment or provide feedback, provide new opportunities for people to present and express themselves online (Birney, Barry, \& Eigeartaigh, 2006; Downes, 2004). Du and Wagner (2005) systematize the rationale for using weblogs as an educational resource or as a pedagogical strategy. As an educational resource, blogs can function as a space for efficient information retrieval or a space for a teacher to provide online information for students. As a pedagogical strategy, blogs can serve as digital portfolios, a space for the exchange of ideas or role-playing, and a space for integration. In summary, the use of weblogs in higher education can enhance the learning and teaching process in multiple ways. In this study, students blogged about topics of their own, without strong instructions about the content required. This didactical approach is very interesting because lecturers are able to observe what students think about a subject, dependent on their previous knowledge, their interests, and their research or studies, without being influenced by input from lecturers. As a result, the content of the lecture becomes more student-centered, but also more flexible. This teaching scenario depends on two crucial factors: the lecturer has to put some effort into collaborating with the students, and the lecturer has to respond to their shared content (Ebner \& Maurer, 2007). Thus, collaboration and communication throughout the process of blog development of blog tend to initiate inventive skills. According to enGauge (NCREL, 2002), twenty-first century skills consist of digital age literacy, inventive thinking and effective communication. In other words, nurturing twenty-first century skills can be initiated through the application and development of blogs.

Blogs can be used in an almost infinite number of ways. For example, they can function as a platform for communication between teachers, students, parents, guardians and the local community to provide general or 
daily updates on what is happening at school with regard to homework assignments, planned field trips, and so on. Blogs can also be used as a platform for knowledge management. Teachers and students can share their reflections, outside material and resources using the blog forum for everyone's benefit, thus forming and maintaining knowledge communities on topics of interest (Prensky, 2001). Thus, blogs can be used as an efficient digital tool for archiving and tracking information for future use (Johnson, 2004).

Another important aspect of blogs is their potential use as a platform for collaboration. Blogs allow students to synthesize knowledge by sharing information, interpretations and opinions, and allow teachers to dissolve classroom walls by inviting outside subject-matter experts, mentors and observers to participate within blog discourse (Timothy \& Jacobson, 2005). Blogs can also potentially aid instructors by creating a place for open disclosure without the instructor's direct presence (Clara, 2007).

The benefits of blogs include lowering barriers to web publishing, and promoting higher-order thinking skills in going beyond knowledge and comprehension to application, analysis, synthesis and evaluation, which often creates a quest for further information to determine the validity of knowledge. Blogs can help students become subject-matter experts and increase students' interest in and ownership of their learning, hence providing opportunities for diverse student perspectives (Krause, 2007). As with many things, blogs are not perfect, as evidenced by some of their limitations such as security and access issues and budget constraints (Krause, 2007).

Recent studies show that most teachers spend little time preparing learning materials (Zakaria \& Iksan, 2007; Bell \& Cowie, 2001). Teachers were also found to be resistant to the adoption of innovative technological learning practices that have the potential to change their classroom routines (Harada, 2003; Fullan, 1998). The reasons are reported to be due to the low quality of software available in schools, discomfort with technological learning environments and a lack of relevant training, and lack of confidence in the outcomes of technological integration. Nevertheless, teachers agree on the need for educational technology and the importance of ICT integration in teaching and learning practices (Woodbridge, 2004). The contradiction between teachers' beliefs in the importance of integrating technology and their real practice in classrooms are due to teachers' current professional development, which gives less focus to the use of technology in classroom activities. Woodbridge (2004) posits that teachers will only integrate technology in their teaching practices when they feel at ease with technology. If technology can be a first step towards transforming teaching and learning, then understanding its pedagogical possibilities can assist teachers in transforming their classroom practice (Johnson \& Liu, 2000).

One of the most important activities for the new millennium is nurturing twenty-first century skills among students, especially for the younger generation, including undergraduates. The aim of this study is to identify:

The perceived usage of weblogs among undergraduate students;

The perceived major benefit(s) of blogging;

The preferred usage of weblogs as a supplement for teaching and learning;

The way students think about weblogs; and

The overall usage of weblogs in relation to twenty-first century skills.

\section{Methodology}

\subsection{Participants}

The participants in this research were 68 second-year pre-service teachers who were enrolled on the GGGE2153 course (Educational Technology). These students were among the total of 150 students who were taking this course. The selection of the participants was based on random sampling.

\subsection{Data Collection Method}

This research employed a quantitative approach that involved the use of a questionnaire as the method of data collection. The questionnaire was developed through six sections: demographic information, perceived usage of weblogs (12 items), perceived benefits of weblogs (eight items), preferred usage of weblogs (seven items), thinking about weblogs (ten items) and the overall usage of weblogs in relation to twenty-first century skills (six items). Apart from the demographic data section, all questions were in the form of a Likert Scale (1: Do not agree at all, to 5: Total Agreement).

\subsection{Data Analysis}

Data analysis was done using SPSS, and involved descriptive analysis, through which the frequency, mean value and standard deviation were derived. 


\section{Results}

\subsection{Gender}

As shown in Table 1, 34 respondents were male pre-service teachers $(50 \%)$, while the other 34 were female $(50 \%)$.

Table 1. Gender of respondents

\begin{tabular}{lll}
\hline Gender & $\mathrm{n}$ & $\%$ \\
\hline Male & 34 & $50 \%$ \\
Female & 34 & $50 \%$ \\
\hline
\end{tabular}

\subsection{Time Spent Daily Surfing the Internet}

As summarized in Table 2, most of the respondents $(79.4 \%, \mathrm{n}=54)$ spent more than three hours daily on the internet. The rest of the respondents $(20.6 \%, \mathrm{n}=14)$ spent less than two hours a day on the internet.

Table 2. Time spent daily surfing the internet

\begin{tabular}{lll}
\hline Time spent & $\mathrm{n}$ & $\%$ \\
\hline Less than 1 hour & 1 & $1.5 \%$ \\
$1-2$ hours & 13 & $19.1 \%$ \\
$3-4$ hours & 21 & $30.9 \%$ \\
5 hours and above & 33 & $48.5 \%$ \\
\hline
\end{tabular}

\subsection{The Perceived Usage of Weblogs}

Table 3 presents the participants' perceived usage of weblogs. The highest mean was for item A11, "I use weblogs to allow others to read my ideas or opinions", which scored $3.84(\mathrm{SD}=0.86)$, followed by item A8, "I use weblogs to discuss and share ideas for assignments", with a mean score of $3.76(\mathrm{SD}=0.92)$ and item A3, "I use weblogs to read supplementary information given by lecturers", with a mean score of $3.72(\mathrm{SD}=0.93)$. The lowest mean was for item A7, "I use weblogs to submit assignments to lecturers", which scored 3.07 (SD = $0.92)$.

Table 3. The perceived usage of weblogs

\begin{tabular}{llll}
\hline Statements & n & Mean & $\begin{array}{c}\text { Standard } \\
\text { deviation }\end{array}$ \\
\hline A1 I use weblogs to contact my lecturers & 68 & 3.29 & 0.88 \\
A2 I use weblogs to download lecture notes and course materials & 68 & 3.35 & 0.91 \\
A3 I use weblogs to read supplementary information given by lecturers & 68 & 3.72 & 0.93 \\
A4 I use weblogs to read mail/notices issued by lecturers & 68 & 3.49 & 1.00 \\
A5 I use weblogs to read messages posted by classmates & 68 & 3.71 & 0.77 \\
A6 I use weblogs to exchange ideas with classmates & 68 & 3.69 & 1.11 \\
A7 I use weblogs to submit assignments to lecturers & 68 & 3.07 & 0.92 \\
A8 I use weblogs to discuss and share ideas for assignments & 68 & 3.76 & 0.92 \\
A9 I use weblogs to perform social interactions with classmates and lecturers & 68 & 3.71 & 0.92 \\
A10 I use weblogs to share PowerPoint presentations with others & 68 & 3.28 & 0.92 \\
A11 I use weblogs to allow others to read my ideas or opinions & 68 & 3.84 & 0.86 \\
A12 I think weblogs can be used in formal and academic contexts & 68 & 1.08 \\
\hline
\end{tabular}




\subsection{The Perceived Major Benefit(s) of Blogging}

For the perceived major benefits of blogging, eight items were developed. Items were submitted to gain feedback regarding the perceived major benefit(s) of blogging. The results of the study (Table 4) show that the means of students' perceived major benefit(s) of blogging ranged from $3.32(\mathrm{SD}=1.04)$ to $4.19(\mathrm{SD}=0.76)$. The highest rated perceived major benefit of blogging was item B1, "Freely sharing personal ideas and opinions with others in a social setting" (mean $=4.19, \mathrm{SD}=0.76$ ), whereas the lowest rated perceived major benefit of blogging was item B4, "Disguising my identity and reducing conflicts when posting opposing views" ( $m e a n=3.32, \mathrm{SD}=$ 1.04).

Table 4. The perceived major benefit(s) of blogging

\begin{tabular}{llll}
\hline Statements & n & Mean & SD \\
\hline B1 Freely sharing personal ideas and opinions with others in a social setting & 68 & 4.19 & 0.76 \\
B2 Communicating more conveniently with others with similar interests & 68 & 3.94 & 0.84 \\
B3 Disguising my identity and posting comments/opinions freely & 68 & 3.65 & 0.97 \\
B4 Disguising my identity and reducing conflicts when posting opposing & 68 & 3.32 & 1.04 \\
views & & & \\
B5 Allowing others to read my information and personal opinions & 68 & 3.96 & 0.85 \\
B6 Allowing me to read other people's messages freely & 68 & 3.96 & 0.80 \\
B7 Allowing me to share and view visual, audio and multi-media files easily & 68 & 3.96 & 0.89 \\
B8 User-friendly operational design and very easy to learn and use & 68 & 3.96 & 0.89 \\
\hline
\end{tabular}

\subsection{Preferred Usage of Weblogs to Enhance Teaching and Learning}

The analysis indicates that students prefer blogging to enhance their teaching and learning. The results of the study show that the overall mean of this question ranged from 3.54 to 3.99 (See Table 5). The highest rated statement was "Discussions/sharing of further study issues" (mean $=3.99, \mathrm{SD}=0.76)$. The lowest score was for "Discussions/sharing part-time job and related issues" (mean $=3.54, \mathrm{SD}=0.91$ ).

Table 5. Preferred usage of weblogs to supplement teaching and learning

\begin{tabular}{llll}
\hline Statements & $\mathbf{n}$ & Mean & SD \\
\hline C1 Sharing PowerPoint presentations with others & 68 & 3.56 & 0.84 \\
C2 Sharing reflections on projects or assignments with others & 68 & 3.87 & 0.62 \\
C3 Discussing/sharing career and job-hunting issues & 68 & 3.59 & 0.80 \\
C4 Discussing/sharing part-time job and related issues & 68 & 3.54 & 0.91 \\
C5 Discussing/sharing further study issues & 68 & 3.99 & 0.76 \\
C6 Discussing/sharing current news or subject-related topics & 68 & 3.97 & 0.83 \\
C7 Discussing/sharing funny games/interesting stories & 68 & 3.88 & 0.92 \\
\hline
\end{tabular}

\subsection{Thinking about Weblogs}

The section on students' thoughts about weblogs had ten sub-constructs. The results of the analysis show that the means ranged from 3.50 to 4.04 (See Table 6). The highest mean was in relation to the statement that weblogs "allow me to express my views freely" (mean $=4.04, \mathrm{SD}=0.72$ ), while the lowest mean was in relation to the statement that weblogs "allow me to develop friendships with lecturers" (mean $=3.50, \mathrm{SD}=0.94)$. This finding reveals that students appreciated the usage of weblogs as weblogs allow them to express their views freely, through which their critical and creative thinking is developed. 
Table 6. Thinking about weblogs

\begin{tabular}{llll}
\hline Statements & n & Mean & SD \\
\hline D1 Weblogs are convenient to be used for learning activities & 68 & 3.72 & 0.77 \\
D2 Weblogs allow me to express my views freely & 68 & 4.04 & 0.72 \\
D3 Weblogs are exciting to use for learning activities & 68 & 3.71 & 0.71 \\
D4 Weblogs are relaxing to use for discussions and exchanging ideas & 68 & 3.93 & 0.65 \\
D5 Weblogs keep me engaged in discussions and exchanging ideas & 68 & 3.81 & 0.74 \\
D6 Weblogs allow me to develop friendships with classmates & 68 & 3.76 & 0.83 \\
D7 Weblogs allow me to develop friendships with lecturers & 68 & 3.50 & 0.94 \\
D8 Weblogs help to keep my attention for learning & 68 & 3.51 & 0.86 \\
D9 Weblogs help to keep my interest in learning & 68 & 3.57 & 0.90 \\
D10 Weblogs allow me to develop better organizational skills & 68 & 3.53 & 0.91 \\
\hline
\end{tabular}

\subsection{Overall Usage of Weblogs in Relation to Twenty-First Century Skills}

The section on the usage of weblogs in relation to twenty-first century skills consisted of seven sub-constructs. Questions were submitted to get students' views on their usage of weblogs in relation to twenty-first century skills. The results of the analysis show that the means for this section ranged between 3.62 and 3.94 (see Table 7). The highest rated statement relating to weblog usage was "Overall, I enjoy using weblogs to share ideas and express opinions" ( mean $=3.94, \mathrm{SD}=0.73)$, whereas the lowest rated statement relating to overall weblog usage in relation to twenty-first century skills was "Overall, I enjoy using weblogs to communicate with classmates" (mean $=3.62, \mathrm{SD}=0.92$ ). The overall mean for the usage of weblog in relation to twenty-first century skills was above 3.50 .

Table 7. Overall usage of weblogs in relation to twenty-first century skills

\begin{tabular}{llll}
\hline Statements & n & Mean & SD \\
\hline E1 Overall, I enjoy using weblogs to communicate with classmates & 68 & 3.62 & 0.92 \\
E2 Overall, weblogs are useful to enhance my active learning & 68 & 3.69 & 0.72 \\
E3 Overall, I find weblogs to be relaxing, easy to use and 'social' & 68 & 3.88 & 0.80 \\
E4 Overall, I enjoy using weblogs to communicate with classmates and & 68 & 3.68 & 0.84 \\
lecturers & & & \\
E5 Overall, I enjoy using weblogs to communicate with others or the public & 68 & 3.76 & 0.79 \\
E6 Overall, I enjoy using weblogs to share ideas and express opinions & 68 & 3.94 & 0.73 \\
\hline
\end{tabular}

\section{Discussion}

The results show a positive impact of weblogs, in that students were seen to use blogs for discussions as well as to share ideas with their classmates. Through collaborative activities, the construction of new knowledge is expected to occur. It can be concluded that, overall, students valued the usage of weblogs as very enjoyable and fun. They also showed positive attitudes towards using weblogs to enhance their learning and communication with their friends and lecturers. The results reveal that, aside from students appreciating the potential of weblogs in education, they felt more motivated to integrate technologies into their future teaching practices. This result highlights the importance of having a learning environment with sufficient technological infrastructure, particularly in all tertiary institutions, so that twenty-first century skills can be successfully instilled in students' daily learning processes. The twenty-first century skills identified in this study comprise skills in using weblogs for active and collaborative learning among students. As the literature shows, the ways in which current school teachers conduct their classroom activities are likely to be impacted by their learning experiences, or the way that they were trained, and therefore it is vital to ensure that during their training, pre-service teachers are exposed to experiences related to a constructivist learning environment (Carolson \& Gadio, 2002). They need to 
be exposed to real pedagogical experiences with the internet in order to understand technology as a tool that can help them to create enriched and collaborative pedagogical experiences. One example of such an approach is through the usage of weblogs, as this study suggests. Weblogs are not just easy to use, but also support learning processes and enhance the organization of knowledge. This indicates that students have positive attitudes towards the usage of weblogs. In this twenty-first century, more skills are needed in order for students to prepare for a better future. It is expected that students be able to apply the knowledge they have gained in the challenges they face in their real lives.

\section{Conclusion and Recommendations}

In accordance with the finding of the study, the main implication is that that application and development of weblogs can be used in order to nurture twenty-first century skills among undergraduates. The findings show that the usage of weblogs has a positive impact on nurturing twenty-first century skills. Teachers or lecturers should therefore involve and engage students in using weblogs as part of their teaching strategy. This can be employed through a variety of activities according to students' abilities.

\section{References}

Bell, B., \& Cowie, B. (2001). Formative assessment in science education. The Netherlands: Kluwer Academic Press.

Birney, R., Barry, M., \& Eigeartaigh, M. (2006). Blogs: enhancing the learning experience for technology students. In E. Pearson, \& P. Bohman (Eds.), Proceedings of ED-MEDIA 2006 (pp. 1042-1046). Orlando, FL: Association for the Advancement of Computing in Education (AACE).

Carlson, S., \& Gadio, C. T. (2002). Teacher professional development in the use of technology. In J. Sikula (Ed.), Handbook on Teacher Education (pp. 978-1029). New York, NY: Macmillan.

Clara, P. (2007). Infusing technology in pre-service teacher education program in Portugal: An experience with Weblog. In R. Craslen et al. (Eds), Proceedings of the $18^{\text {th }}$ international Conference of the Society for information Technology and teacher Education (pp. 2027-2034), SITE 2007. Chesapeake, VA: AACE.

Downes, S. (2004). Educational Blogging. Educause Review, 39(5), 14-26. Retrieved from http://www.educause.edu/pub/er/erm04/erm0450.asp?bhcp=1

Du, H. S., \& Wagner, C. (2005). Learning with weblogs: An empirical investigation. In Proceedings of the $38^{\text {th }}$ Hawaii International Conference on Systems Sciences. http://dx.doi.org/10.1109/HICSS.2005.387

Ebner, M., \& Maurer, H. (2007). Blogging in Higher Education. Proceedings of E-Learn 2007 (pp. 767-774). Quebec City: Canada.

Fullan, M. (1998). The meaning of Educational Change: A Quarter of Century of Learning. In A. Hargreaves, A. Liebermen, M. Fullan, \& D. Hopkins (Eds.), International Handbook of Educational Change (pp. 214-228). The Netherlands: Kluwer Academic Publishers.

Harada, V. (2003). From instruction to construction: Learning in the information age. In M. Fitzgerald, M. Orey, \& R. Branch (Eds.), Educational Media and Technology Yearbook 2003 (pp. 40-48). Westport, CT: Libraries Unlimited.

Johnson, D. L., \& Liu, L. (2000). First steps towards a statistically generated information technology integration model. Computers in Schools, 16(2), 3-12. http://dx.doi.org/10.1300/J025v16n02_02

Johnson, T. (2004). Wag the blog: How reliance on traditional media and the internet influence credibility perceptions of weblog among blog use. Journal Mass Communications, 81(3), 622-642. http://dx.doi.org/10.1177/107769900408100310

Krause, K. (2007). E-learning and the e-Generation: The changing face of higher education in the $21^{\text {st }}$ Century. In J. Lockard, \& M. Pegrum (Eds.), Brave new classrooms: Educational democracy and the internet (pp. 125-140). New York: Peter Lang Publishing.

NCREL. (2002). EnGauge $21^{\text {st }}$ Century Skills: Digital literacies for a digital age. Retrieved from http://www.ncrel.org/engauge/skills.html

Prensky, M. (2001). Digital Natives digital immigrants. On The Horizon. NCB University Press, 9(5). Retrieved from http://hfmboces.org

Rosenbloom, A. (2004). The blogosphere. Communications of the ACM, 47(12), 31-33.

Timothy, M., \& Jacobson, M. (2005). Preservice teacher's reflections and attitudes towards using WebQuests. 
Proceedings of 3rd International Conference on Education and Information Systems, Orlando, 10-15.

Walker, J. (2003). Weblog: definition for the routledge encyclopedia of narrative theory. Retrieved from http://huminf.uib.no/ jill/archives/blog_theorising/final_version_of_weblog_definition

Woodbridge, J. (2004). Technology integration as a transforming teaching strategy: Techlearning. Retrieved from http://www.techlearning.com/story/showArticle.jhtml?articleID=17701367

Zakaria, E., \& Iksan, Z. (2007). Promoting cooperative learning in Science and Mathematics Education: A Malaysian Perspective. Eurasia Journal of Mathematics, Science \& Technology Education, 3(1), 35-39.

\section{Copyrights}

Copyright for this article is retained by the author(s), with first publication rights granted to the journal.

This is an open-access article distributed under the terms and conditions of the Creative Commons Attribution license (http://creativecommons.org/licenses/by/3.0/). 